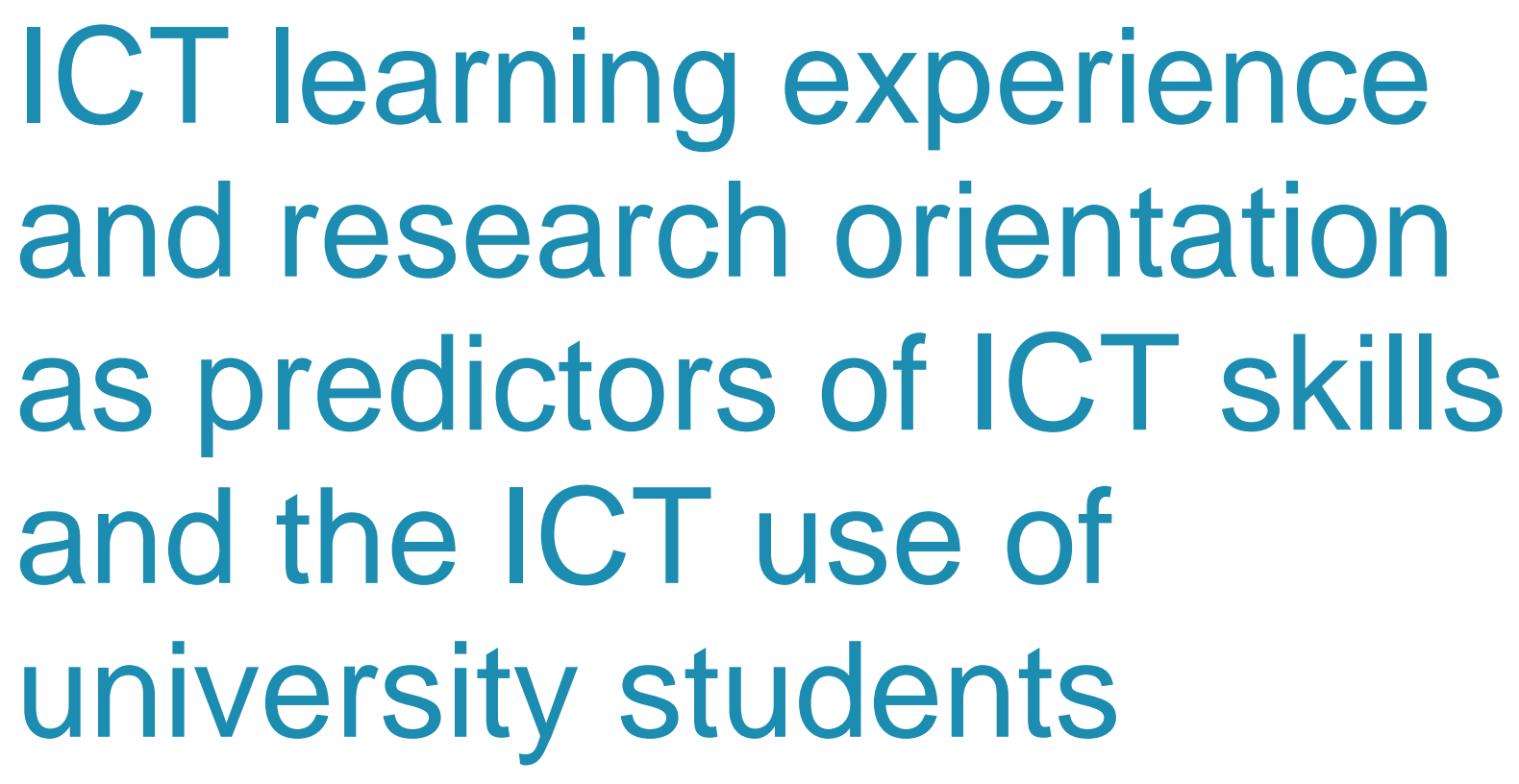

The final publication is available at http://link.springer.com/article/10.1007/s10639-014-9310-3

Verhoeven Jef C., Heerwegh Dirk \& De Wit Kurt (2014) "ICT learning experience and research orientation as predictors of ICT skills and the ICT use of university students", Education and Information Technologies. 33 pp. doi: 10.1007/s10639-014-9310-3 
The final publication is available at http://link.springer.com

\title{
ICT learning experience and research orientation as predictors of ICT skills and the ICT use of university students
}

\section{Jef C. Verhoeven, Dirk Heerwegh, Kurt De Wit ${ }^{1}$}

\begin{abstract}
Since our first studies of information and communications technology (ICT) skills and ICT use at universities in 2004, ICT and its use by students has changed greatly. In order to obtain a more detailed picture of ICT skills, we first construct a new instrument to measure the self-perception of ICT skills (49 items) and of ICT use (53 items) by students. This allows us to find some patterns for ICT skills and ICT use. In order to explain these patterns, two basic hypotheses are formulated. The first suggests that positive ICT learning experiences at home, in school, and with peers could contribute to mastering a higher level of ICT skills and more frequent use of ICT among bachelor's students, a hypothesis that aligns with Dewey's learning theory. The second hypothesis suggests that there is a similarity between the characteristics of information systems and scientific research, and that students who identify more with scientific research would be more likely to have greater ICT skills and a higher frequency of ICT use. Both hypotheses are tested among bachelor's students, using some important contextual variables (gender, domain of study, ICT course in secondary school or at university, and education level of parents). It can be concluded that there is a relationship between the ICT learning experience and the research-oriented identity commitment of bachelor' students on the one hand, and their command of ICT skills and the frequency of use of computers, ICT instruments, and ICT programs on the other.
\end{abstract}

\section{Introduction}

In spite of the ever-increasing number of applications for information and communications technology (ICT) in modern society, numerous studies show that people still vary greatly with regard to their level of ICT skills and how often they use ICT. Many reasons have been suggested to explain these differences, such as gender, age, education, access to ICT, family culture, wealth, computer anxiety, belief in the usefulness of computers, the difference between rural and urban areas, etc. (see for example, Broos 2005; Becker 2006; Colley and Comber 2003; Wang et al. 2009; Carlsson et al. 2006; Chatzoglou et al. 2009; Cho et al. 2009; Lee 2008; Lee 2010; Lee et al. 2009; Teo et al. 2009; Wu et al. 2007; Hargittai 2010; Salajan et al. 2010).

\footnotetext{
1 J. C. Verhoeven $\left(^{*}\right)$

Centre for Sociological Research, University of Leuven, Parkstraat 45 bus 3601, 3000 Leuven,

Belgium

e-mail: jef.verhoeven@soc.kuleuven.be

D. Heerwegh

Leuven Statistic Research Centre, University of Leuven, Celestijnenlaan 200b bus 5307, 3001 Leuven

e-mail: dirk.heerwegh@Istat.kuleuven.be

K. De Wit

Office for Educational Policy, University of Leuven, Krakenstraat 3 bus 5200, 3000 Leuven, Belgium

e-mail: kurt.dewit@dowb.kuleuven.be
} 
Even when focusing on more homogeneous populations comprising higher education students, the members of which are commonly referred to as 'digital natives', ICT skills and the use of ICT are found to be far from equally distributed. Interestingly, ICT capacities do not necessarily improve over time (as commonly assumed), but may actually diminish between first and senior year at the university (Kaminski et al. 2009) or between first and $5^{\text {th }}$ year in medical school (Strømsø et al. 2004), and it is not certain that current cohorts are as skillful as those of some years ago (De Wit et al. 2012).

The 'digital differentiation approach' considers these differences to be the consequence of a process of definition made by people using ICT (Peter and Valkenburg 2006; van Dijk 2006). According to this perspective, some basic skills are required in order to make use of information technology, but what people actually do with the technology depends on what they consider to be meaningful to themselves and others. This explains why people who have had comparable access to computers and the Internet, may use these instruments differently, which in turn may explain the existence of a gap between groups with regard to their level of ICT skills and use of ICT equipment.

At the level of secondary and primary education, previous studies described below have shown a positive association between certain types of ICT uses or skills and achievement in the fields of science and mathematics, and negative associations between other types of ICT use and achievement in these fields.

Based on data collected among German and American secondary school students in 2000 for the assessment PISA project by the OECD, Papanastasiou et al. (2005) found that students who used a PC at home to produce papers attained higher achievements in science (see also Luu and Freeman 2011).

Kubiatko and Vlckova (2010) found a positive relationship between the science knowledge test and the ICT familiarity test taken by secondary school students in the Czech Republic. Luu and Freeman (2011) found that Internet browsing was positively related to scientific literacy. Similarly, Chen and Fu (2009) observed that eighth-grade students in Taiwan who practiced online searching achieved better results in the entrance exams for high school. Demir et al. (2010) found that Turkish secondary school students who were more confident in using computers tended to have better scores for mathematics than those who were less confident.

According to McMahon (2009), the use of ICT in classrooms can affect more general 'higher order thinking skills'. Based on a study among ninth-grade girls in Australia, he concluded that an ICT rich environment is significantly correlated with the development of students' critical thinking skills. Moreover, students with better computer programming skills also scored higher for critical thinking. 
However, some studies have shown a negative association between ICT skills and achievements in science and/or mathematics. Luu and Freeman (2011) found that use of productivity and entertainment software was negatively associated with scientific literacy. Akyol et al. (2010) made the observation that among Turkish elementary school students, those who had a computer, or a computer with an Internet connection, were more likely to get a lower score in science achievement. This was also observed by Won and Han (2010). They used data collected within the TIMSS (Trends in Mathematics and Science Studies) framework in 2003 among American and Korean secondary school students. Achievement was found to be negatively associated with playing games on a computer after controlling for the number of books at home and the education level of the parents (see also Eow et al. 2009). Chen and Fu (2009) studied the effects of ICT use on high school entry exam results. They found that when students used the Internet for socializing and game playing, the results tended to be lower. Papanastasiou et al. (2005) found that students who had access to a computer at school, and who frequently used this for programming, had lower levels of achievement in science.

Former studies have shown that at least ICT use might be positively related with achievement in science subjects and improved critical thinking among young students, but have not investigated this link at the level of university education. Accepting that the study of science familiarizes students with the procedures of scientific research, we can hypothesize that students interested in scientific research will also be interested in the knowledge and application of ICT. In this current research, based on theoretical considerations presented in the next section we expect to find an association between the level of command of ICT skills and ICT use, and the degree to which university students are research oriented. As explained in the methodology section, on the basis of a questionnaire filled out by 1,232 bachelor's students, we investigate the association between ICT use and skills, and research orientation, taking into account the ICT learning experiences of the students and some important contextual variables such as gender, the education level of the parents, and the domain of study. Section 4 presents a short overview of students' access to PCs and the internet, their learning experiences, and their attitudes toward scientific research. In Sections 5 and 6, both the learning experience model and the identity commitment model are tested as predictors of, respectively, ICT skills and the frequency of ICT use. In the final sections, we discuss the results, draw some conclusions, and refer to some implications.

\section{Theory}

\subsection{The role of experiential learning}

Learning is not limited to formal learning organizations such as schools, but takes place in all kinds of situations where people meet each other (Cox 2012). From a very young age, children experience pleasure 
when they are capable of doing what others do. They feel they belong to a particular group because they can act like the other group members, whether family members or playmates (Dewey 1933: 206, 257). Unmistakably, John Dewey (1933: 258; 1938: 236; Kolb and Kolb 2005) stressed the power of experience in this learning process. He emphasized the advantage of belonging to a group where the objective of learning is highly appreciated (Dewey 1933: 38; Dewey 1938: 25) and he underlined the capacity of this to stimulate the motivation to learn more about what people need in order to function in a group. These opinions are shared by other researchers. Jeffrey et al. (2011) refer to several other researchers in stressing the importance of the personal relevance of the learning content for a successful learning process. This also partly explains success in learning ICT. Although in many countries ICT is formally taught in schools, an important part of ICT knowledge is gained at home or among friends. In Western societies, ICT is widespread and computers and the Internet have a place in many families. Parents and siblings play an important role in making this technology accepted. Children discover how much fun it is to play games on the computer and, more importantly, feel that learning how to work with ICT instruments is also highly appreciated by parents and siblings.

Research has shown that the ICT experience of children at home is very important, certainly for their ICT skills in primary school (Anastasiades et al. 2008; Aslanidou and Menexes 2008; Barron et al. 2010; Vekiri, 2010a; Zhao et al. 2010). Because of this, Dewey would probably not use the term digital natives, as ICT activities are not native, but learned in interaction with others. Nevertheless, this does not mean that all children take advantage of the presence of computers at home or in the possession of friends to the same extent. In the above-mentioned research, differences are observed between urban and rural areas, and between middle-class and other families, with urban and middle-class families showing more open access to a computer and the Internet, and a higher command of ICT skills and the ability to work with the Internet than other families. One of the reasons is that in more modernized areas and in middle-class families, the necessary equipment is more prevalent and gives children more opportunities to experience using a PC and the Internet. Children whose parents work with a computer for their job also seem to benefit from this (Barron et al. 2010). Boys seem to have more positive experiences with ICT than girls do, as they have more opportunities to experiment with a computer (Vekiri 2010b; Volman and Van Eck, 2001). Vekiri and Chronaki (2008) suggest that the stereotypes parents share about boys and girls have contributed to the gender gap in using a computer or the Internet. Parents socialize their sons and daughters differently and this has consequences with regard to the gender gap in ICT skills.

Vekiri and Chronaki (2008; Vekiri 2010a) mention research where the link between the socio-economic position of the parents of the students and ICT use is supported in elementary schools and in secondary and higher education. However, using regression analysis, they came to the conclusion that home 
computer access, frequency of use, variety of activity, and perceived parental and peer support were not or were just marginally related to students' self-efficacy and value beliefs. Similar critical observations were made by Verhoeven et al. (2010) and De Wit et al. (2012). In a regression model where in addition to social background (the socio-economic position and education level of the parents of the students), the variables of usefulness and control of the computer, computer anxiety, and Internet competence were included in explaining the frequency of use of computers for study, chatting, and games by secondary school students, no substantial relationship was found with social background. The only relationship found was a lower frequency of computer use for recreation by working-class students compared with other students. The same phenomenon was observed by these authors among university freshmen. The socioeconomic position of the students in combination with other variables showed a minor influence on the ICT skills and the frequency of ICT use of university freshmen. This indicates that influences experienced at a very young age do not always have apparent consequences in secondary school and university. Moreover, De Wit et al. (2012) also found that the effect of influence might change over years. For example, they found that in 2005 , students whose father or mother had completed higher education were less capable of installing a computer than other students were, but that this relationship was the opposite in 2009. In addition, in 2005 students whose father had completed higher education chatted more online than other students, and those whose mother had completed higher education chatted less. In 2009 both relationships were reversed. In other words, situational developments might change previous relationships.

Peers also play a role in learning about ICT and the Internet. Vekiri (2010a) found support in relevant literature for the hypothesis that lower-class children take even more advantage of their peers than other children do, because peers could compensate for what they could not find at home. This has been confirmed in our own research among university freshmen (Verhoeven et al. 2010). Students mention friends as the second most important source of instruction about ICT (mean score $=3.29$ on a scale of 1 to 5). Nevertheless, students overwhelmingly consider themselves as the most important instructors of ICT for themselves (mean score $=4.02$ ), thereby offering a good example of what J. Dewey would call agents, not simple receptors (Dewey 1917; Evans 2000).

This leads to the hypothesis that students whose families, peers, and teachers more intensely support contact with and instruction about ICT, will possess more developed ICT skills and will use ICT more often than students who did not grow up in such an ICT-oriented environment. Nevertheless, based on relevant literature, this relationship is not expected to be very strong.

2.2. The role of students' identity commitment 
Earlier research has indicated that the vocational orientation of university students significantly influences the use of ICT and the command of ICT skills (Verhoeven et al. 2010; De Wit et al. 2012). Vocational orientation could be called a form of commitment, as defined by Burke and Reitzes (1991) in the following way: "(it) refers to the sum of the forces, pressures, or drives that influence people to maintain congruity between their identity setting and the input of reflected appraisals from the social setting". The identity setting of a university student is, among other things, composed of a belief in his or her academic competence, a vocational orientation (studying for a particular profession), and an orientation toward becoming a scientific researcher or another professional. Interactions with others may support or blur this identity and can influence a student to pursue or abandon these intentions. If the identity commitment is strong, a student will adhere to the expectations of the group that link him or her to a particular identity setting. A student who benefits significantly from living close to this student setting will very probably be more committed to that identity than other students. Burke and Reitzes (1991) discerned two bases of commitment. First, cognitive bases refer to positive rewards coming from interacting with people as a result of maintaining the expected identity. Assuming that a student has an elementary knowledge of ICT, stimulating the appraisal of other students might motivate a student to work harder toward mastering ICT skills. Second, socio-emotional bases refer to ties between people who share the same position and experience the recognition of others as supportive confirmation of the adequacy of their behavior. When a student experiences the acceptance of other students, he or she will most likely try to maintain interactions with these positive, rewarding colleagues.

A stronger commitment to a professional career in research or in another area, and a belief that ICT will be a necessary or inevitable component of a future career, might lead students to have a stronger commitment to using ICT and using it more frequently. Moreover, using ICT involves taking a number of steps that are also part of carrying out scientific research. This similarity might add (albeit not at a conscious level) to a stronger link between training in scientific research as a part of an identity setting, and knowledge of ICT skills and the use of ICT.

Scientific research has characteristics similar to that of an information system, which Zwass (2012) defined as: "an integrated set of components for collecting, storing, and processing data and for delivering information, knowledge, and digital products". Scientific research starts with the question of why a particular phenomenon is what it is or why it functions in the way that it does. Researchers start with some hypothetical explanations and collect data in order to test whether a hypothesis is proven or found to be incorrect. Observations, methodologies, and interpretations are stored, because there should always be an opportunity to check and recheck the research data and results. It is also important to have an instrument in order to rapidly retrieve any data that researchers might be interested in. The process of scientific 
research does not stop there. Results should be made available to colleagues and a wider audience; they should be publically displayed. Research is also expected to be useful (See also Pole and Lampard, 2002). This all takes place in collaboration and in discussion with the wider scientific community. Researchers collaborate locally but also internationally. Datasets are transmitted from one continent to another, discussed by researchers who live far away from each other, but jointly publish in journals that are read throughout the world. They meet at international seminars and conferences, teach each other's students, engage in common projects, etc. In other words, scientific research shares many characteristics of information systems as described by O'Brien and Marakas (2009: 4): “An information system can be any organized combination of people, hardware, software, communications networks, data resources, and policies and procedures that stores, retrieves, transforms, and disseminates information in an organization". Each information system comprises some basic activities. In order to obtain information that has to be processed, a worker needs instruments to capture this information (for instance, a keyboard or a scanner). This captured information has to be transmitted or processed to another device (for instance, another PC in a network) in order to work with it later. Therefore, it has to be stored (for instance, on a hard disk or a USB stick). When needed in a later process, this information needs to be retrieved. This procedure takes the results of the storage process and uses them to elaborate the information. The old information (output information products) is used to create new information, to reorganize the information, to recalculate what has been retrieved, or similar operations. At the end of this process, the results are shown to an observer who might be interested in the results of analyzing the information. At the end of the input, processing, output, and storage, a control of the system performance should be established.

This brings us to the hypothesis that students who are interested in scientific research and/or want to become researchers will be more open to mastering ICT skills and/or will make greater use of computers and the Internet for their studies than other students will. Indeed, ICT offers them useful instruments for attaining the targets that researchers have in mind and helps them to be rewarded for showing a commitment to their identity setting.

\section{Methodology}

Data for this project was gathered through an online questionnaire filled out by bachelor's students at the University of Leuven (KU Leuven), which is one of the largest Belgian universities. It is a comprehensive university with a wide range of scientific disciplines and domains of study. Although the university buildings are spread across the town, the university has a well-developed intranet system offering broadband Internet access to all students, even those in private rented accommodation. In 2012, the university was attended by 40,257 students, among whom $45 \%$ were studying at bachelor's level, $31 \%$ at 
master's level, and $11 \%$ were working for a PhD. In this project, we focus on bachelor's students who had passed their first-year exams and would not take their final bachelor's exam in 2013. This is a population comprising 3,609 students. Most of them had been at the university for at least a year and were supposed to be familiar with the ICT equipment of the university and the expectations of the staff concerning ICT use in and outside classes. Some 1,232 students answered an online questionnaire between 13 November 2012 and 18 December 2012. Students received up to two e-mail reminders after an initial e-mail invitation to participate in the survey. The analysis used here involves 1,180 students who responded to at least $75 \%$ of the questions and fell within the age range of up to 25 . Because the multivariate sample distribution for gender, age, and faculty deviated to some extent from the population distribution, a weighting factor was calculated by iterative proportional fitting.

We test our hypotheses using two models (see Figures 1 and 2). The first model focuses on the learning experience of the students, and the second on their identity commitment. Both models are expected to contribute to the prediction of self-perceived ICT skills, and self-reported frequency of ICT use.

Figure 1. Explanatory model 1: learning experience

\begin{tabular}{|c|c|}
\hline Predictor variables & Dependent variables \\
\hline $\begin{array}{l}\text { - family PC experience at home (Home_pc) } \\
\text { - learn from family (Home_learn) } \\
\text { - support from family (Home_sup) } \\
\text { - family PC experience at work (Work_pc) } \\
\text { - learn from peers (Peer_learn) } \\
\text { - support from peers (Peer_sup) } \\
\text { - learn from teachers (Teach_learn) } \\
\text { - support from teachers (Teach_sup) } \\
\text { - age of first PC experience } \\
\text { - self-study of ICT } \\
\text { Context: } \\
\text { - female (1) or male (0) (dummy variable) } \\
\text { - domain of study (Humanities students } \\
\text { (Human) = } 1 \text {; others }=0 \text { ) } \\
\text { - ICT course in secondary school } \\
\text { (ICT_secon = } 1 ; \text { no course }=0 \text { ) }\end{array}$ & $\begin{array}{l}\text { ICT competences } \\
\text { - Maintenance of PC (Maint) } \\
\text { - Word } \\
\text { - Spreadsheet (calculation, style } \\
\text { change, work on graphs) } \\
\text { - Database } \\
\text { - Presentation program (work on data, } \\
\text { presentation change) } \\
\text { - Browser (technical use of browser, } \\
\text { information collection) } \\
\text { - Communication } \\
\text { Frequency of ICT use } \\
\text { - Use of PC for study (Freq_pc_stud) } \\
\text { - Use of PC not for study } \\
\text { (Freq_pc_nstud) } \\
\text { - Use of ICT instruments for study } \\
\text { (Freq_instr_stud) } \\
\text { - Use of ICT instruments not for study }\end{array}$ \\
\hline
\end{tabular}




\begin{tabular}{|l|l|l|}
\hline $\begin{array}{l}\text { - at least one parent attained higher education } \\
(\text { HEpar }=1 \text {; parents had no higher education } \\
=0)\end{array}$ & $\begin{array}{l}\text { (Freq_instr_nstud) } \\
\text { - Use of ICT programs for study } \\
\text { (Freq_progr_stud) } \\
\text { - Use of ICT programs not for study } \\
\text { (Freq_progr_nstud) }\end{array}$ \\
\hline
\end{tabular}

Figure 2. Explanatory model 2: identity commitment

\begin{tabular}{|c|c|}
\hline Predictor variables & Dependent variables \\
\hline $\begin{array}{l}\text { - academic self-perception (Acadsc) } \\
\text { - vocational or professional orientation } \\
\text { (Profor) } \\
\text { - attitude toward science (Attit_science) } \\
\text { - intention to become a researcher (Intent_sc) } \\
\text { - intention to become something other than a } \\
\text { researcher (Intent_oth) } \\
\text { - Scientific research needs ICT } \\
\text { (ICT_science) } \\
\text { Context: } \\
\text { - female (1) or male (0) (dummy variable) } \\
\text { - domain of study (Humanities students } \\
\text { (Human) = 1; others = 0) } \\
\text { - ICT course in secondary school } \\
\text { (ICT_secon = 1; no course = 0) } \\
\text { - at least one parent attained higher education } \\
\text { (HEpar = 1; parents had no higher education } \\
\text { = 0) }\end{array}$ & $\begin{array}{l}\text { ICT competences } \\
\text { - Maintenance of PC (Maint) } \\
\text { - Word } \\
\text { - Spreadsheet (calculation, style } \\
\text { change, work on graphs) } \\
\text { - Database } \\
\text { - Presentation program (work on data, } \\
\text { presentation change) } \\
\text { - Browser (technical use of browser, } \\
\text { information collection) } \\
\text { - Communication } \\
\text { Frequency of ICT use } \\
\text { - Use of PC for study (Freq_pc_stud) } \\
\text { - Use of PC not for study } \\
\text { (Freq_pc_nstud) } \\
\text { - Use of ICT instruments for study } \\
\text { (Freq_instr_stud) } \\
\text { - Use of ICT instruments not for study } \\
\text { (Freq_instr_nstud) } \\
\text { - Use of ICT programs for study } \\
\text { (Freq_progr_stud) } \\
\text { - Use of ICT programs not for study } \\
\text { (Frea nroor_nstud) }\end{array}$ \\
\hline
\end{tabular}




\subsection{Dependent variables}

\subsubsection{ICT competences}

The seven ICT competences in Figures 1 and 2 are measured using scales consisting of several items. These scales have been used in previous research and refined over the years to capture new types of ICT use (e.g. inclusion of references to social networking sites [SNS]; cf. Verhoeven et al. 2010; De Wit et al. 2012). To ensure that the current study measures ICT skills with an up-to-date instrument having good measurement properties, new items were added to our existing scales and the complete measurement instrument was subjected to a pilot test.

Based on a review of several instruments, in particular ECDL Syllabus 5.0 (ECDL 2010), new items were developed. A paper questionnaire containing the existing and new items (a total of 123 items: 19 for maintenance of a PC; 19 for word processing; 24 for spreadsheets; 20 for databases; 17 for presentation software; 13 for browsers; and 11 for communication) was tested in a non-random sample of 85 university students. The response format for all items was identical (a five-point Likert-type rating scale ranging from 'totally not true for me' to 'totally true for me' with the midpoint 'more or less true for me').

The resulting data was analyzed using exploratory factor analysis (EFA) and confirmatory factor analysis (CFA) in Mplus version 4.0. The EFA was used to identify appropriate items and the CFA was conducted primarily to assess goodness of fit. The selection of the final items was based on the results of the factor analyses and an evaluation of the distribution of the individual items (items with strong ceiling or floor effects were deleted). In total, 49 items were included in the final questionnaire. The items were distributed over the seven ICT skill domains as follows: 7 for maintenance of the PC; 6 for word processing; 14 for spreadsheets; 6 for databases; 6 for presentation software; 7 for browsers; and 3 for communication (see Table 1).

The data obtained from the main survey (1,180 students) was subjected to confirmatory factor analysis (CFA) in Mplus version 4.0. The model tested the theoretically expected structure and proved to fit the data well $($ CFI $($ comparative fit index $)=0.95$; TLI $($ Tucker Lewis Index $)=0.95$; RMSEA (root mean square of error approximation $)=0.030 ; \operatorname{SRMR}($ standardized root mean square residual $)=0.040)$. This model includes three substantively defensible error covariances. Regression-based factor scores were calculated with SAS PROC FACTOR (for each scale separately) and are used in further analyses (DiStefano et al. 2009).

\subsubsection{Frequency of ICT use}


The frequency with which students use a computer, ICT instruments (hardware), and ICT programs (software) was measured separately for study purposes and for all other purposes. Students were asked how frequently they engaged in specific behavior (surfing the Internet, e-mailing, chatting, goal-oriented online searching, downloading movies or music, participating in newsgroups, writing blogs or wikis, and playing games - the last item was not asked when gauging ICT use for study purposes), how often they used ICT hardware (use of a PC or laptop, Internet, mobile, iPad or tablet, iPod, iPhone or smartphone, digital camera, and e-reader), and how often they used specific software (word processing, spreadsheets, databases, SNS, Twitter, virtual learning environments, drawing software, statistical programs, qualitative data analysis programs, and specialized software). The response options were: daily (score $=6$ ); four to five times a week $($ score $=5)$; two or three times a week $($ score $=4)$; weekly $($ score $=3)$; monthly $($ score $=$ $2)$; less than once a month ( $($ core $=1)$; and never $($ score $=0)$.

An average score was calculated across all items of each of the three variables separately for study and for non-study purposes (use of a computer, use of ICT instruments, and use of ICT programs), for use in further analyses.

Table 1. Scales of ICT skills and item examples

\begin{tabular}{|c|c|}
\hline ICT skills and subscales & Item example \\
\hline Maintenance (7 items) (Cronbach's $\alpha=0.86$ ) & - I can make a backup of the data on my hard disk \\
\hline Word processor $(6$ items) (Cronbach's $\alpha=0.84$ ) & $\begin{array}{l}\text { - I can use a text editor to add a background color to a } \\
\text { table }\end{array}$ \\
\hline Digital spreadsheets & \\
\hline - Calculate (3 items) (Cronbach's $\alpha=0.94)$ & $\begin{array}{l}\text { - I can work in a digital spreadsheet with some simple } \\
\text { functions (Average, Sum, Round). }\end{array}$ \\
\hline - $\quad$ Style change (8 items) (Cronbach's $\alpha=0.93$ ) & $\begin{array}{l}\text { - I can print out on one page one sheet from a } \\
\text { spreadsheet that does not fit on one page }\end{array}$ \\
\hline $\begin{array}{l}\text { Work on graphs ( } 3 \text { items) (Cronbach's } \alpha= \\
0.92 \text { ) }\end{array}$ & - I can create a chart with digital spreadsheets \\
\hline Database (6 items) (Cronbach's $\alpha=0.98)$ & $\begin{array}{l}\text { - In a database program I can add or remove records in a } \\
\text { table }\end{array}$ \\
\hline Presentation program & \\
\hline - Work on data (4 items) (Cronbach's $\alpha=0.93$ ) & $\begin{array}{l}\text { - In a presentation program } I \text { can change the column } \\
\text { width or row height of a table }\end{array}$ \\
\hline $\begin{array}{l}\text { - Presentation change (2 items) (Cronbach's } \alpha= \\
0.71)\end{array}$ & $\begin{array}{l}\text { - In a presentation program I can insert a different } \\
\text { template into a presentation that primarily works on a }\end{array}$ \\
\hline
\end{tabular}




\begin{tabular}{|l|l|}
\hline Browser & different template \\
$-\quad \begin{array}{l}\text { Technical use of browser (4 items) (Cronbach's } \\
\alpha=0.82)\end{array}$ & - I can use a Web browser to delete cookies \\
$-\quad \begin{array}{l}\text { Information collection (3 items) (Cronbach's } \alpha \\
=0.75)\end{array}$ & $\begin{array}{l}\text { - I can search an Internet Encyclopedia with a Web } \\
\text { browser }\end{array}$ \\
Communication (3 items) (Cronbach's $\alpha=0.72)$ & $\begin{array}{l}\text { - Using a special program I can have a conversation with } \\
\text { my partner, while we both view files on each other's } \\
\text { computers }\end{array}$ \\
\hline
\end{tabular}

\subsection{Independent variables}

\subsubsection{Learning experiences}

Learning experience of ICT was measured using several indicators. The survey questionnaire included items on whether the student's father, mother, or siblings used a computer at home (Home_pc; score range $=0-3$ ), and at work (Work_pc; score range $=0-3$ ). Both situations might create a positive attitude toward using computers.

Three questions referred to how much students had learned about ICT from family members (father, mother, and siblings), peers, and teachers. The response options were 'I did not learn anything from (e.g. my father)', 'I have learned a little, much, very much from (e.g. my father)', and 'not applicable'. All answers about the degree of learning from family members (Home_learn) were averaged to obtain a scale that ranged from 1 (learned nothing) to 4 (learned very much). An identical procedure was followed for learning from peers (Peer_learn) and from teachers (Teach_learn).

Three additional questions collected information about who might be able to provide support while working with ICT. Students were asked how often they could request help if they experienced problems with a computer or the Internet. A distinction was made between support from family (Home_sup), peers (Peer_sup), and teachers (Teach_sup), and the same response options were provided: never; seldom; mostly; always; and not applicable. The average scores were calculated for each source of support, with the scale ranging from 1 (no support at all) to 4 (maximum support).

Dewey's learning theory also points to the relevance of the learning content for a learner. If something is highly relevant for a learner, he or she will stress this by engaging in learning activities. To obtain a 
measurement of this, the survey asked how much respondents had learned about computers and the Internet by themselves (score range $=1-4$ ), and their age when they had first started using a computer.

\subsubsection{Identity commitment}

Identity commitment is composed of four indicators. First, academic self-perception or academic selfconcept (Acadsc) was measured with 7 items such as 'I rate myself highly in terms of my academic ability as an undergraduate', 'I have great self-confidence in my ability to succeed academically at university', etc. (based on Bennett 2009). The same response options as for the indicators for ICT skills were provided.

Table 2. Scales related to identity commitment and item examples

\begin{tabular}{|c|c|}
\hline Scales & Item example \\
\hline - Professional or vocational orientation & choice, I opt for courses that seem \\
\hline (Profor) $(6$ items) (Cronbach's $\alpha=0.73)$ & useful to me for my future profession \\
\hline - Academic self-perception (Acadsc) (6 items) & - I have great self-confidence in my ability to \\
\hline (Cronbach's $\alpha=0.83$ ) & succeed academically at university \\
\hline - Attitude toward scientific research & - Scientific research is the most interesting thing \\
\hline (Attid_science) (12 items) (Cronbach's $\alpha=0.87$ ) & that we learn here \\
\hline $\begin{array}{l}\text { - Intention to become a researcher (Intent_sc) }(7 \\
\text { items) (Cronbach's } \alpha=0.90)\end{array}$ & - I want to become a researcher in a company \\
\hline $\begin{array}{l}\text { - Intention to become something other than a } \\
\text { researcher (Intent_oth) ( } 5 \text { items) (Cronbach's } \alpha= \\
0.68)\end{array}$ & $\begin{array}{l}\text { - In the future, I would like to give advice to clients } \\
\text { or patients }\end{array}$ \\
\hline $\begin{array}{l}\text { - Necessity of ICT for a researcher (ICT_science) } \\
(9 \text { items) (Cronbach's } \alpha=0.86)\end{array}$ & $\begin{array}{l}\text { - A researcher must be able to work properly with a } \\
\text { database }\end{array}$ \\
\hline
\end{tabular}

Second, a Likert scale to measure the extent to which a student is 'vocation directed' was used (Profor) (Vermunt 1994). It contains five items such as 'What I want to acquire above all through my studies is a professional skill', 'the main goal I pursue in my studies is to prepare myself for a profession', etc. and could be answered with the same response options as the academic self-perception scale.

A CFA was conducted on the items intended to measure academic self-perception and being vocation directed. There was one item that loaded on both factors and in addition had low standardized factor loadings $(<0.40)$, it was therefore removed from the CFA analysis. Two error covariances were allowed in the final model $(\mathrm{CFI}=0.97 ; \mathrm{TLI}=0.96 ; \mathrm{RMSEA}=0.047 ; \mathrm{SRMR}=0.044)$. With regard to the ICT skills scales, SAS PROC FACTOR was used to calculate regression based factor scores for use in further analyses. 
Third, in order to measure the attitude toward scientific research, a Likert scale was developed with 12 items, such as: 'Scientific research is fun', 'I would enjoy school more if they did not bother us with scientific research', etc. The list of scales for appraising science or some disciplines is very varied (see for example Wareing 1982; Wareing 1990; Germann 1988; McCleary and Brown 2003; Tuan et al. 2005; George 2006; Kind et al. 2007; McCloskey 2008; Bennett and Hogarth 2009). We followed a scale used by Cheung (2009) concerning the appraisal of chemistry by secondary school students, but adapted the items for the appraisal of scientific research (attit_science). This scale also differs from Cheung's scale by including negatively worded items. EFA using SAS PROC FACTOR shows that the 12 items form a good scale, and the regression-based factor scores are used in further analyses (see Table 2).

Fourth, 13 survey items were included that gauged the students' intentions regarding their later professional life. Example items include: 'In my professional life I want to conduct scientific research', 'In my professional life I want to teach', and 'In my professional life I would prefer to work with people'. EFA with SAS PROC FACTOR shows that two dimensions exist in these items: one refers to the intention of a student to become a researcher (Intent_sc; 7 items), the second to the intention to pursue a career other than research (Intent_oth; 5 items). One survey item did not load well on either dimension and was left out of the analysis. Regression based factor scores were calculated with PROC FACTOR and are used in subsequent analyses.

Our hypothesis was that students who are more research oriented will also have a higher level of ICT skills and use ICT more often than other students. We took into account that this relationship might not be equally strong for all study disciplines, and therefore included items to measure the extent to which students themselves are convinced that ICT is necessary for a scientific researcher. This information was collected with nine items such as: 'Today a scientific researcher cannot work properly without a computer', 'A scientific researcher should be capable of working properly with database software', etc. (ICT_science). EFA using SAS PROC FACTOR supports our expectation that these nine items form a good scale and also provides regression-based factor scores for use in further analyses.

\subsubsection{Contextual variables}

Research has shown that there are still factors that might create inequality of opportunities for some categories of the population (see Section 1). Former research indicates the importance of gender, domain of study, taking an ICT course in secondary school, attending classes at the university where a computer is used, and the education level of parents for the development of ICT skills and the frequency of ICT use by students (Verhoeven et al. 2010; De Wit et al. 2012). 
Gender is included as dummy variable (female $=1$, male $=0$ ). With regard to the domain of study, we expect that science and bio-medical students (score $=0$ for the dummy Human) will be more skilled in and more engaged in ICT activities than humanities students (score $=1$ for the dummy Human). Having attended classes dedicated to ICT in secondary school and at university might also stimulate students' ICT skills and frequency of ICT use. Two dummy variables (one for secondary school and one for university) are included in the models $(0=$ did not attend at least one ICT class, $1=$ did attend at least one ICT class $)$. At university, this dummy refers to attending classes where a computer is used by the students.

Similar to many other opportunities in life, living in a well-to-do family creates more opportunities for easy and comprehensive access to ICT at home. Belonging to a particular social class creates or diminishes opportunities. While it is recognized that social class is a complex concept, we opt for the education level of the parents as a crude indicator of social class. Students with at least one parent with a college or university degree were coded 1 on the dummy variable HEpar, while 0 refers to other students.

\subsubsection{Inspection of the distribution of dependent variables}

In the next sections, regression analyses are used to test the hypotheses. Prior to commencing analyses, it was checked whether the residuals of the dependent variables were normally distributed and had a constant variance (homoscedasticity). As the scores for ICT skills show strong ceiling effects (see Table 3), simple linear regression analysis seemed inappropriate. Alternative methods include (ordered) logistic regression analysis and censored regression analysis (Tobit regression). We opted for the latter method, implemented in SAS PROC QLIM. In this model, the limits of the independent variable are set at a specific value at the top (upper bound) and/or at the bottom (lower bound) of the variable. Moreover, the model takes into account any problems of heteroscedasticity.

Table 3. Average scores (range 1-5), standard deviations, and lower quartile of ICT skills

\begin{tabular}{|l|c|c|c|}
\hline ICT skills & Mean score $(\mathrm{N})$ & Standard deviation & Lower quartile \\
\hline Maintenance of PC & $4.24(1169)$ & 0.83 & 3.70 \\
Word & $4.66(1171)$ & 0.59 & 4.57 \\
Digital spreadsheets & & & \\
$\quad$ - calculation & $3.91(1169)$ & 1.28 & 3.00 \\
$\quad$ - style change & $3.68(1159)$ & 1.14 & 2.95 \\
$\quad$ - work on graphs & $3.89(1163)$ & 1.24 & 3.00 \\
Database & $2.53(1162)$ & 1.41 & 1.00 \\
Presentation program & & & 3.51 \\
$\quad$ - work on data & $4.12(1167)$ & 1.07 & 3.57 \\
$\quad$ - presentation change & $4.16(1173)$ & 1.00 & \\
\hline
\end{tabular}




\begin{tabular}{|c|c|c|c|}
\hline Browser & $3.89(1172)$ & 1.20 & 2.88 \\
- technical use of browser & $4.60(1171)$ & 0.70 & 4.26 \\
- information collection & $2.93(1173)$ & 1.32 & 1.90 \\
Communication & & & \\
\hline
\end{tabular}

The regressions on the frequency of ICT use do not show the same problems as the ICT skills scores.

Scores are not extreme (see Table 4), residuals are normally distributed, and most regressions do not face heteroscedasticity. Regressions with problems of heteroscedasticity are analyzed using SAS PROC ROBUSTREG (MM estimation).

We also investigated potential problems of multicollinearity, but found no indications that multicollinearity jeopardized the validity of any of our regression models.

Table 4. Average frequency (range 0-6) and standard deviation of ICT use by bachelor's students

\begin{tabular}{|l|c|c|}
\hline & Mean score & $\begin{array}{c}\text { Standard } \\
\text { deviation }\end{array}$ \\
\hline Frequency of PC use for study (Freq_pc_stud) & 2.61 & 0.84 \\
Frequency of PC use not for study (Freq_pc_nstud) & 2.91 & 0.80 \\
Frequency of use of ICT instruments for study (Freq_instr_stud) & 2.05 & 0.65 \\
Frequency of use of ICT instruments not for study (Freq_instr_nstud) & 3.05 & 0.67 \\
Frequency of use of ICT programs for study (Freq_progr_stud) & 1.70 & 0.59 \\
Frequency of use of ICT programs not for study (Freq_progr_nstud) & 1.34 & 0.66 \\
\hline
\end{tabular}

\section{Short overview of the main variables}

Before examining the results of our analyses, this section presents a short overview of the access of students to computers and the Internet, their learning experiences, and their attitudes toward scientific research.

A computer is basic equipment for a student today: of the students surveyed, $99.5 \%$ of those living in rented accommodation and $99.7 \%$ of those living at home use a computer. Of the latter, $27 \%$ share this computer with another person, whereas among students living in rented rooms only one student does. Of the computers that are at the disposal of the students most of the time about $88 \%$ are laptops, $7 \%$ are desktops, 3\% notebooks, and the rest netbooks or tablets. All the students, except one, have access to the Internet in their room and/or at home. Some $82 \%$ of the students living in rented accommodation have broadband Internet access both at home and in their rented accommodation, whereas the students living at home always have a broad band connection at home. It should also be noted that the student without a 
connection in his room or at home can use the Internet, as the university provides many places where students have free access to PCs and the Internet and all students receive an e-mail address from the university.

Table 5. Average score and standard deviation of ICT learning experience scales

\begin{tabular}{|l|c|c|}
\hline ICT learning experiences & Mean score (score range) & Standard deviation \\
\hline Home_pc & $2.67(0-3)$ & 0.57 \\
Work_pc & $1.72(0-3)$ & 0.82 \\
Home_learn & $1.81(1-4)$ & 0.49 \\
Home_sup & $2.20(1-4)$ & 0.78 \\
Peer_learn & $2.54(1-4)$ & 0.67 \\
Peer_sup & $3.11(1-4)$ & 0.74 \\
Teach_learn & $1.81(1-4)$ & 0.50 \\
Teach_sup & $1.48(1-4)$ & 0.63 \\
Self-study & $3.49(1-4)$ & 0.63 \\
\hline
\end{tabular}

Knowing that $85 \%$ of the students have at least one parent with a higher education diploma, it can be expected that use of a computer and the Internet are self-evident for most of these families (see Table 5). The use of a PC at home by parents and siblings gets an average score of 2.67 out of 3, and $89 \%$ of the parents of these students and $90 \%$ of their siblings use a computer at home. Some $77 \%$ of the fathers, and $63 \%$ of the mothers of the students also utilize a PC at work (score 1.72 out of 3 ). This shows that the use of a PC belongs to the daily life of most of these students and their families. Many of them started using a $\mathrm{PC}$ at a young age: the average age is $11.91(\mathrm{std} \mathrm{dev}=2.46)$, a quarter of them were ten or younger.

Nevertheless, this does not mean that students believe they learned most about computers and the Internet from family members. They believe that this knowledge is mainly the result of self-study (score 3.49 out of 4). They consider the second most important informant about ICT is their peers (score 2.51 out of 4), the third, their teachers (score 1.72 out of 4 ), and the fourth, their family (score 1.63 out of 4 ). When students need support for solving PC or Internet problems, they first ask their peers (score 3.08 out of 4), second their parents and/or siblings (score 2.13 out of 4), and third, all types of teachers in secondary school and at university (score 1.26 out of 4 ).

Most students attended an ICT course in secondary school - only 15\% did not. At university, some classes focus on special computer programs, but not on the basics of ICT. During the semester when the interviews were conducted, 53\% of students attended one or more classes where students work on a PC. For $50 \%$ of these students this happened weekly, for $20 \%$ several times a week, and for $30 \%$ monthly. 
Table 6. Average score (range $1-5$ ) and standard deviation of academic and scientific research orientation scales

\begin{tabular}{|l|c|c|}
\hline Scales & Mean score & $\begin{array}{c}\text { Standard } \\
\text { deviation }\end{array}$ \\
\hline Academic self-perception(Acadsc) & 3.30 & 0.76 \\
Vocational or professional orientation (Profor) & 3.60 & 0.84 \\
Attitude toward scientific research (Attit_science) & 3.27 & 0.67 \\
Intention to become a researcher(Intent_sc) & 2.56 & 0.88 \\
Intention to become something other than a researcher(Intent_oth) & 3.17 & 0.71 \\
ICT, a requisite for a researcher (ICT_science) & 4.02 & 0.58 \\
\hline
\end{tabular}

Scientific research is a positive factor, though a score of 3.27 out of 5 is not very high (see Table 6). To become a scientific researcher is not a priority for many students (score 2.56 out of 5). This might be the result of the knowledge among students that in order to become a researcher at the university a candidate should achieve higher than average. Moreover, at this stage of their education students do not always have a clear picture of what a researcher is supposed to do. They are more interested in becoming a consultant, a teacher, a manager, or something else other than a scientific researcher (score 3.17 out of 5).

Nevertheless, most students are convinced that a scientific researcher cannot function properly without sufficient knowledge of the basic ICT skills (score 4.02 out of 5).

\section{Learning experience and identity commitment as predictors for ICT skills}

It would seem safe to suppose that (at least some) ICT skills are widespread among students. After all, PCs are present in primary and secondary schools and most students have already had to carry out tasks using a computer and the Internet at home. Writing papers, searching the Internet for a purpose, and making presentations are daily practice in secondary schools. Therefore, it is expected that most students at university would be convinced that they could work with a word processor, search the Internet, and make a presentation. Table 3 confirms this expectation. It is clear that most students know how to work with a word processor (score 4.66 out of 5) and are convinced that they can do a search on the Internet (4.6 out of 5). A large proportion of the students are certain that they can maintain a computer (score 4.24 out of 5), change the style of presentations (score 4.16 out of 5), or work on the data of a presentation (score 4.12 out of 5). However, they feel they are less capable of making use of the technicalities of a browser (score 3.89 out of 5) or working with digital spreadsheets. With regard to the latter, they believe that they are better at making calculations (score 3.91 out of 5) or working on graphs (score 3.89 out of 5) than making style changes (score 3.68 out of 5) in spreadsheets. In comparison with the former skills, most students are less familiar with the more special types of communication (score 2.93 out of 5). It should be stressed that communication skills are not about chatting or participating in SNS, because only $4 \%$ of the students did not chat on the Internet this academic year and only $8 \%$ did not use a SNS (see 
Table 1 for an item example). The students are the least familiar with databases. Most students have only some vague knowledge of this subject and $25 \%$ of them do not know anything at all about it.

Can learning experience and identity commitment explain some of the knowledge level of these eleven ICT skills? Neither model is very strong, but both show many significant predictors for ICT skills. First, we look at the learning experience model. Learning experience can explain $29 \%$ of the variance in the computer maintenance skills of students and $25 \%$ of the variance in the skills to use the technicalities of a browser (see Table 7). However, learning experience explains only $19 \%$ or less of the variance in all other ICT skills, with the contribution being the weakest for word processing skills $(6.2 \%)$ and the two skills linked with presentation programs (5.4\% and 5.6\%). These skills are widespread among the students (see Table 3). 
Table 7. Learning experience as predictor of ICT skills (censored regression model [Proc Qlim Tobit specification]).

\begin{tabular}{|c|c|c|c|c|c|c|c|c|c|c|c|}
\hline \multirow[t]{2}{*}{ Predictors } & \multirow[t]{2}{*}{ Maint } & \multirow[t]{2}{*}{ Word } & \multicolumn{3}{|c|}{ Digital Spreadsheet } & \multirow[t]{2}{*}{ Database } & \multicolumn{2}{|c|}{ Presentation program } & \multicolumn{2}{|c|}{ Browser } & \multirow[t]{2}{*}{ Communication } \\
\hline & & & $\begin{array}{c}\text { XLS1 } \\
\text { calculation }\end{array}$ & $\begin{array}{c}\text { XLS2 } \\
\text { Style } \\
\text { change }\end{array}$ & $\begin{array}{c}\text { XLS3 } \\
\text { Work on } \\
\text { graphs }\end{array}$ & & $\begin{array}{c}\text { PPT1 } \\
\text { Work on } \\
\text { data }\end{array}$ & $\begin{array}{c}\text { PPT2 } \\
\text { Presentation } \\
\text { change }\end{array}$ & $\begin{array}{c}\text { BROWS1 } \\
\text { technical } \\
\text { use of } \\
\text { browser }\end{array}$ & $\begin{array}{c}\text { BROWS2 } \\
\text { Information } \\
\text { collection }\end{array}$ & \\
\hline Intercept & -0.572 & 0.149 & 0.129 & -0.611 & -0.085 & -1.896 & -0.499 & -0.419 & 0.312 & 0.402 & -0.541 \\
\hline Home pc & - & - & - & - & - & - & - & - & & & - \\
\hline Home_learn & - & - & - & - & - & - & - & - & - & - & - \\
\hline Home_sup & - & - & - & - & - & - & - & - & $-0.171 * *$ & - & - \\
\hline Work_pc & - & - & - & - & - & - & - & - & - & - & - \\
\hline Peer_learn & - & - & - & $-0.129 *$ & $-0.163 *$ & - & - & - & - & - & - \\
\hline Peer_sup & - & - & - & - & - & - & - & - & - & - & - \\
\hline Teach_learn & - & - & $0.357 * * *$ & $0.208 * *$ & $0.257 * *$ & $0.287 * *$ & - & - & - & - & - \\
\hline Teach_sup & & - & - & - & - & - & - & - & - & - & - \\
\hline $\begin{array}{l}\text { Age at first PC } \\
\text { experience }\end{array}$ & $-.078 * * *$ & $-0.065 * *$ & $-0.064 * * *$ & $-0.043 * * *$ & $-0.062 * * *$ & $-0.059 * *$ & $-0.065^{* *}$ & $-0.061 * * *$ & $-0.069 * * *$ & $-0.115 * * *$ & $-0.060 * * *$ \\
\hline Self-study & $0.624 * * *$ & $0.466^{* * *}$ & $0.305 * * *$ & $0.326 * * *$ & $0.351 * * *$ & $0.294 * * *$ & $0.515 * * *$ & $0.404 * * *$ & $0.521 * * *$ & $0.795 * * *$ & $0.385 * * *$ \\
\hline Female & $-.844 * * *$ & - & $-0.495 * * *$ & $-0.339 * * *$ & $-0.345^{* * *}$ & $-0.397 * * *$ & $-0.254 *$ & $-0.255^{* *}$ & $-1.004 * * *$ & $-0.903 * * *$ & $-0.397 * * *$ \\
\hline Human & - & $-0.490 * * *$ & $-0.817 * * *$ & $-0.391 * * *$ & $-0.700 * * *$ & $0.510 * * *$ & - & - & - & - & - \\
\hline ICT_secon & $0.276^{* *}$ & $0.317 *$ & $0.390^{* *}$ & $0.371 * * *$ & $0.390 * *$ & $0.388 * *$ & $0.261 *$ & $0.225^{*}$ & $0.197 *$ & - & - \\
\hline HEPar & - & $-0.450 * *$ & - & $-0.233^{* *}$ & $-0.263^{*}$ & - & - & $-0.259 *$ & - & - & - \\
\hline $\mathrm{R}^{2}$ & 0.292 & 0.062 & 0.190 & 0.162 & 0.190 & 0.080 & 0.054 & 0.056 & 0.251 & 0.097 & 0.120 \\
\hline
\end{tabular}

$* \mathrm{p}<0.05$

$* * \mathrm{p}<0.01$

$* * * \mathrm{p}<0.001$ 
Of the ten independent variables that are directly linked with the learning experience of the students, two contribute significantly to the explanation for all ICT skills. The strongest of the two is self-study, followed by age at the first experience of using a computer. The general pattern is that students who score high for self-study also score high for all ICT skills. However, the age when students first used a computer had negligible effects (although statistically very significant) on their ICT skills. The other forms of learning experience help little in better predicting ICT skills, except for the skills to use a spreadsheet, a browser, and a database. The more students have learned from their teachers the higher they score for spreadsheet and database skills, although self-study is here also deemed more important than information from teachers. Some relationships are hard to understand and we mention two. First, the more students have learned from their peers, the less they score on changing styles and working on graphs in spreadsheets. Second, the more support students receive at home, the lower they score for the skills to work with a browser. These negative relationships need more research to understand why they develop in this way.

Contextual variables also play an important role. Except for word processing, female students score lower than male students for all ICT skills, a phenomenon that is often observed. Students who participated in an ICT course in secondary school score higher than other students for nine of the eleven ICT skills in our observation. Humanities students score significantly lower on spreadsheet skills and word processing skills than science students do. Why students in the field of humanities score higher than science students for database skills is not immediately clear. This is also true for the relationship between higher education level of one of the parents and knowledge of ICT skills. Contrary to our expectation, students whose parents took higher education do not score higher for ICT skills. Additional research will be needed in order to explain this unexpected finding.

The second model, identity commitment, is weaker than the first. Nevertheless, it does unveil some interesting predictors for ICT skills. Some $20.3 \%$ of the variance in the technical use of a browser can be explained by this model, as can $17.6 \%$ of the variance in the maintenance skills of students. The model also explains between $16.3 \%$ and $15.1 \%$ of spreadsheet skills. Less variance is explained for the other skills (between $10.1 \%$ and $3.2 \%$ ). 
Table 8. Identity commitment as predictor of ICT skills (censored regression model [Proc Qlim Tobit specification]).

\begin{tabular}{|c|c|c|c|c|c|c|c|c|c|c|c|}
\hline \multirow[t]{2}{*}{ Predictors } & \multirow[t]{2}{*}{ Maint } & \multirow[t]{2}{*}{ Word } & \multicolumn{3}{|c|}{ Digital Spreadsheet } & \multirow[t]{2}{*}{ Database } & \multicolumn{2}{|c|}{ Presentation program } & \multicolumn{2}{|c|}{ Browser } & \multirow[t]{2}{*}{ Communication } \\
\hline & & & $\begin{array}{c}\text { XLS1 } \\
\text { calculation }\end{array}$ & $\begin{array}{c}\text { XLS2 } \\
\text { Style } \\
\text { change }\end{array}$ & $\begin{array}{c}\text { XLS3 } \\
\text { Work on } \\
\text { graphs }\end{array}$ & & $\begin{array}{c}\text { PPT1 } \\
\text { Work on } \\
\text { data }\end{array}$ & $\begin{array}{c}\text { PPT2 } \\
\text { Presentation } \\
\text { change }\end{array}$ & $\begin{array}{c}\text { BROWS1 } \\
\text { technical } \\
\text { use of } \\
\text { browser }\end{array}$ & $\begin{array}{l}\text { BROWS2 } \\
\text { Information } \\
\text { collection }\end{array}$ & \\
\hline Intercept & 0.625 & 0.686 & 0.917 & 0.330 & 0.679 & -0.762 & 0.391 & 0.452 & 0.884 & 1.302 & 0.309 \\
\hline Acadsc & - & $0.189 * *$ & $0.123^{*}$ & - & $0.098 *$ & - & - & & - & $0.199 * *$ & \\
\hline Profor & - & - & - & $0.099 * *$ & - & $0.117 *$ & $0.136^{*}$ & $0.146 * *$ & - & - & - \\
\hline Attit_science & $0.219 * * *$ & $0.256^{* *}$ & - & - & $0.128 *$ & - & $0.247 * *$ & $0.191 * *$ & $0.135 *$ & 0219* & $0.112 *$ \\
\hline Intent_oth & - & - & - & - & - & - & $0.136^{*}$ & - & - & - & $0.146 * * *$ \\
\hline Intent_sc & - & - & - & $0.100 *$ & - & - & & - & - & & \\
\hline ICT_science & $0.210 * * *$ & $0.368 * * *$ & $0.232 * * *$ & $0.191 * * *$ & $0.201 * * *$ & $0.146 * *$ & $0.295 * * *$ & $0.286^{* * *}$ & $0.142 * * *$ & $0.344 * * *$ & $0.125 * * *$ \\
\hline Female & $-0.979 * * *$ & - & $-0.547 * * *$ & $-0.435 * * *$ & $-0.411 * * *$ & $-0.431 * * *$ & $-0.389 * * *$ & $-0.308 * * *$ & $-1.191 * * *$ & $-1.012 * * *$ & $-0.542 * * *$ \\
\hline Human & - & $-0.239 *$ & $-0.678 * * *$ & $-0.271 * * *$ & $-0.575 * * *$ & $0.593 * * *$ & - & - & - & - & - \\
\hline ICT_secon & $0.347 * * *$ & $0.393 * *$ & $0.421 * * *$ & $0.384 * * *$ & $0.435 * *$ & $0.442 * *$ & $0.377 * *$ & $0.335 * *$ & $0.242 *$ & - & - \\
\hline HEPar & - & - & - & - & - & - & - & - & $-0.205^{*}$ & - & - \\
\hline $\mathrm{R}^{2}$ & 0.176 & 0.092 & 0.163 & 0.152 & 0.151 & 0.058 & 0.055 & 0.073 & 0.203 & 0.032 & 0.101 \\
\hline
\end{tabular}

$* \mathrm{p}<0.05$

$* * \mathrm{p}<0.01$

$* * * \mathrm{p}<0.001$ 
Table 8 shows that the more students believe that a scientific researcher needs a good knowledge of ICT skills, the more they know about the different ICT skills. This is also true for students who place a high value on scientific research, but not for all ICT skills; notably style changes in and calculation skills with spreadsheets, and working with databases. Contrary to our expectations, the intention to become a researcher only positively predicts competence with style changes in spreadsheets, and the intention to become something other than a researcher only predicts the ability to work on data in a presentation program and in communications. The predictive power of these variables is below our expectations.

We also expected that a positive academic self-perception and a high vocational orientation would contribute to a better knowledge of ICT skills, because ICT might be helpful for study and research. This is shown to be only partly true. The higher the academic self-perception of students the better knowledge they have of the skills to work with a word processor, to do calculations or work on graphs in spreadsheets, and to collect information with the help of a browser. When students are more vocationally orientated they think they are more capable of making style changes in spreadsheets, or working with databases, or with presentation programs.

Again, similar to Model 1, contextual variables provide important predictors for the ICT skills of students. Gender is the strongest predictor of all the variables in this model, except for word processing. Female students are less acquainted with ICT skills than male students. Students who attended an ICT course in secondary school score higher for ICT skills (except for information collection and communication) than other students. Humanities students seem to know less about working with spreadsheets or a word processor than science students, but have a better understanding of databases. For other ICT skills, there is no difference between the two groups.

Students whose parents did not graduate in higher education believe they have a better knowledge of how to handle some of the technical aspects of a browser than other students do, but this is the only skill where a difference between these two groups can be found. The ICT head start that students of the more privileged families might have had, does not show at university. In addition, no differences are found with regard to the knowledge of ICT skills for students who did or did not attend an ICT course at the university during the semester when the survey was conducted (not included in Tables 7 or 8).

6. Learning experience and identity commitment as predictors for the frequency of ICT use Turning to the frequency of ICT use instead of ICT skills, we again test both models as predictors. Table 4 has already shown that computers are more frequently used for purposes other than study (score 2.91 out of 6) than for study (score 2.61 out of 6). This is also true with regard to the use of ICT instruments 
(respectively scores of 3.05 and 2.05). However, students do use ICT presentation programs more frequently for study (score 1.7 out of 6) than for non-study purposes (score 1.34 out of 6).

Table 9 and Table 10 show in more detail that the majority of students use computers daily, but mainly for non-study purposes. More than four fifths of the students surf the Internet daily for fun, and about three quarters send e-mails to friends daily. Chatting is also popular: six tenths do this daily for fun. These figures are much lower when they are in connection with study: respectively $54 \%, 51 \%$, and $29 \%$. Other activities, such as downloading music or films, participating in newsgroups, writing blogs or wikis, and playing games are less popular, even when they are not related to study purposes.

Table 9. Frequency of computer use for study $(\%)$

\begin{tabular}{|c|c|c|c|c|c|c|c|c|}
\hline \multirow[t]{2}{*}{ Computer use } & \multicolumn{8}{|c|}{ Frequency } \\
\hline & Never & $\begin{array}{c}\text { Less than } \\
\text { once a } \\
\text { month }\end{array}$ & monthly & weekly & $\begin{array}{c}2 \text { or } 3 \\
\text { times a } \\
\text { week }\end{array}$ & $\begin{array}{c}4 \text { or } 5 \\
\text { times a } \\
\text { week }\end{array}$ & daily & total \\
\hline Surfing & 0.39 & 1.08 & 2.49 & 12.40 & 15.23 & 13.98 & 54.43 & 100 \\
\hline E-mail & 0.47 & 1.33 & 4.42 & 12.48 & 14.25 & 15.97 & 51.09 & 100 \\
\hline Chatting on the Internet & 9.22 & 7.02 & 8.28 & 19.62 & 16.35 & 10.79 & 28.72 & 100 \\
\hline $\begin{array}{l}\text { Purposive searching on } \\
\text { the Internet }\end{array}$ & 0.15 & 1.35 & 7.16 & 20.62 & 24.14 & 20.53 & 26.05 & 100 \\
\hline Downloading music & 62.71 & 12.64 & 9.36 & 7.55 & 2.95 & 1.37 & 3.41 & 100 \\
\hline Downloading films & 66.49 & 12.76 & 8.78 & 6.90 & 2.02 & 0.82 & 2.25 & 100 \\
\hline Newsgroups & 66.37 & 10.76 & 5.53 & 9.20 & 3.05 & 1.56 & 3.53 & 100 \\
\hline Writing blogs or wikis & 86.00 & 6.41 & 3.12 & 2.92 & 1.04 & 0.14 & 0.37 & 100 \\
\hline
\end{tabular}

Table 10. Frequency of computer use not for study (\%)

\begin{tabular}{|c|c|c|c|c|c|c|c|c|}
\hline \multirow[t]{2}{*}{ Computer use } & \multicolumn{8}{|c|}{ Frequency } \\
\hline & Never & $\begin{array}{l}\text { Less } \\
\text { than } \\
\text { once a } \\
\text { month }\end{array}$ & monthly & weekly & $\begin{array}{c}2 \text { or } 3 \\
\text { times a } \\
\text { week }\end{array}$ & $\begin{array}{c}4 \text { or } 5 \\
\text { times a } \\
\text { week }\end{array}$ & daily & total \\
\hline Surfing & 0.40 & 0.45 & 0.29 & 2.47 & 3.25 & 9.34 & 83.80 & 100 \\
\hline E-mail & 0.32 & 0.48 & 1.11 & 6.43 & 6.26 & 11.54 & 73.85 & 100 \\
\hline Chatting on the Internet & 4.20 & 2.91 & 2.67 & 6.88 & 7.66 & 13.55 & 62.12 & 100 \\
\hline $\begin{array}{l}\text { Purposive searching on the } \\
\text { Internet }\end{array}$ & 0.57 & 1.29 & 4.85 & 16.90 & 14.95 & 19.12 & 42.31 & 100 \\
\hline Downloading music & 19.47 & 17.00 & 22.00 & 19.00 & 7.79 & 4.63 & 10.11 & 100 \\
\hline Downloading films & 34.70 & 14.89 & 17.32 & 15.13 & 7.90 & 3.05 & 7.01 & 100 \\
\hline Newsgroups & 65.28 & 10.87 & 5.74 & 6.50 & 3.36 & 2.17 & 6.09 & 100 \\
\hline Games on Internet & 47.90 & 16.40 & 12.34 & 8.75 & 5.05 & 3.29 & 6.26 & 100 \\
\hline Games on PC & 45.82 & 19.12 & 12.00 & 7.71 & 4.75 & 4.40 & 6.21 & 100 \\
\hline Writing blogs or wikis & 86.88 & 6.93 & 2.26 & 2.05 & 0.56 & 0.38 & 0.96 & 100 \\
\hline
\end{tabular}


A similar varied picture is found for the frequency of use of ICT instruments and programs (not shown in tables). For instance, computers and the Internet are used daily by $93 \%$ of the students, but an e-reader was never used by $92 \%$ of the students during this academic year, and an iPad or tablet by only $76 \%$. Most students used the local virtual learning environment (98\%), a word processor (95\%), SNS (86\%), or a presentation program (81\%) in this academic year for study; the figures for non-study purposes are respectively $22 \%, 81 \%, 82 \%$, and $34 \%$.

Given this varied picture of the frequency of use of computers, ICT instruments, and ICT programs, the question is whether our two models can help to predict the variation. The learning experience model does not explain a large proportion of the variance of the frequency of use, but as was the case with ICT skills, it provides some significant variables that allow a better prediction of the dependent variable, namely PC use for non-study purposes (17.5\%) and the use of ICT programs for study (11.5\%). For all other dependent variables, the proportion of explained variance is $6.3 \%$ or lower. 
Table 11. Learning experience as predictor of frequency of use of a PC, ICT instruments, or ICT programs (linear regression analysis)

\begin{tabular}{|c|c|c|c|c|c|c|}
\hline Predictors & Freq_pc_stud $^{\mathrm{b}}$ & Freq_pc_nstud $^{\mathrm{b}}$ & Freq_instrum_stud ${ }^{\mathrm{b}}$ & Freq_instrum_nstud ${ }^{\mathrm{a}}$ & Freq_progr_stud $^{b}$ & Freq_progr_nstud ${ }^{b}$ \\
\hline Intercept & 0 & 0 & 0 & 2.310 & 0 & 0 \\
\hline Home_pc & - & - & - & - & - & - \\
\hline Home_learn & - & - & - & - & - & - \\
\hline Home_sup & - & - & - & - & - & $-0.092 *$ \\
\hline Work_pc & - & - & - & - & - & $0.090 * *$ \\
\hline Peer_learn & $0.094 * *$ & - & $0.085^{*}$ & - & $0.109 * *$ & - \\
\hline Peer_sup & $0.087 *$ & $0.107 * *$ & - & $0.062 *$ & $0.076 *$ & $0.121 * * *$ \\
\hline Teach_learn & - & - & - & - & $0.170 * * *$ & - \\
\hline Teach_sup & - & - & - & - & - & - \\
\hline $\begin{array}{l}\text { Age at first PC } \\
\text { experience }\end{array}$ & - & $-0.179 * * *$ & $-0.117 * * *$ & $-0.018 *$ & $-0.097 * *$ & $-0.111 * * *$ \\
\hline Self-study & - & $0.133 * * *$ & - & $0.135 * * *$ & $0.068^{*}$ & $0.106 * * *$ \\
\hline Female & $-0.090 * *$ & $-0.286 * * *$ & - & - & $-0.065^{*}$ & - \\
\hline Human & $0.126 * * *$ & $0.144 * * *$ & - & $0.115^{* *}$ & $-0.096 * *$ & $0.066^{*}$ \\
\hline ICT_secon & - & - & - & - & - & - \\
\hline HEPar & - & - & - & - & - & - \\
\hline $\begin{array}{l}\text { Adj. } R^{2} \\
F\end{array}$ & $\begin{array}{l}0.039 \\
4.05 * * *\end{array}$ & $\begin{array}{l}0.175 \\
16.87 * * *\end{array}$ & $\begin{array}{l}0.026 \\
3.00 * * *\end{array}$ & 0.032 & $\begin{array}{l}0.115 \\
10.59 * * *\end{array}$ & $\begin{array}{l}0.063 \\
6.01 * * *\end{array}$ \\
\hline \multicolumn{7}{|l|}{$\begin{array}{l}* \mathrm{p}<0.05 \\
* * \mathrm{p}<0.01 \\
* * * \mathrm{p}<0.001\end{array}$} \\
\hline
\end{tabular}


With regard to the frequency of PC use, it is remarkable that the age at the time of first using a computer and self-study are significant predictors for frequency of use for non-study purposes, but not for study (see Table 11). The younger students were when they started using a computer or the more they invested in self-study, the more they use a PC for non-study purposes. Peers also play an important role, both for study and for non-study purposes: when students learned from peers and/or are supported by peers they spend more time on a PC. Two of the contextual factors have some meaning for computer use (both for study and non-study purposes): women use a PC less than men do, and humanities students use a PC more frequently than science students do. ICT courses in secondary school and the education level of parents, however, do not contribute to a better prediction of PC use.

The prediction of the frequency of using ICT instruments for both study and non-study purposes can be significantly improved by two variables (see Table 11). Again, these are the starting age of computer use and peer learning. For non-study purposes, the domain of study and peer support can be added: students in the humanities and those who enjoy more support from peers have a higher chance of more frequently using ICT instruments for non-study purposes. Other variables do not seem to have a significant meaning for the frequency of use of different ICT instruments.

The frequency of use of ICT programs for study and non-study purposes is more sensitive to the variables of the learning experience model. A young age of first using a PC, support from peers, and self-study allow better predictions for the frequency of use of ICT programs. In addition, the domain of study of the student creates better predictions: ICT programs will be used more by science students than by humanities students for study purposes, but for non-study purposes the reverse is true. Table 11 also shows that women use ICT programs less frequently for study than men do, and that students who learned more from teachers and peers about ICT will use ICT programs for study more often. Although attending university courses in which a computer is used does not explain significantly the mastering of ICT skills (see section 5), this variable is a significant predictor (standardized estimate $=0.161 ; \mathrm{p}<0.0001$ ) (figure not included in Table 11) of the frequency of the use of ICT programs for study. Moreover, Table 11 shows that it lets the difference between male and female students disappear, which implies that the study situation contributes to a more frequent and more gender-equal use of ICT programs.

The second model expresses the relevance of identity commitment for the frequency of the use of a PC, ICT instruments, or ICT programs by students. Here, two important factors of identity commitment are the students' professional orientation (Profor) and their belief in their own academic capacities (Acadsc). However, it turns out that this model does not have much explanatory value for either the frequency of use of a computer, ICT instruments, or ICT programs. 
The identity commitment model explains $5.3 \%$ of the variance in frequency of PC use for study and $10 \%$ for non-study purposes (see Table 12). All other $\mathrm{R}^{2}$ values in Table 12 are smaller or almost equal to zero. 
Table 12. Identity commitment as predictor of frequency of use of a PC, ICT instruments, or ICT programs (linear regression analysis; standardized parameters)

\begin{tabular}{|c|c|c|c|c|c|c|}
\hline Predictors & Freq_pc_stud ${ }^{\mathrm{a}}$ & Freq_pc_nstud ${ }^{\mathrm{a}}$ & Freq_instrum_stud ${ }^{\mathrm{a}}$ & Freq_instrum_nstud ${ }^{\mathrm{a}}$ & Freq_progr_stud ${ }^{\mathrm{b}}$ & Freq_progr_nstud ${ }^{b}$ \\
\hline Intercept & 2.567 & 2.929 & 1.986 & 2.781 & 0 & 0 \\
\hline Acadsc & - & - & - & $0.053 *$ & - & - \\
\hline Profor & $0.087 * * *$ & - & $0.058 * *$ & - & - & - \\
\hline Attit_science & & - & $0.085 * *$ & - & $-0.101 *$ & \\
\hline Intent_oth & $0.081 * *$ & - & $0.047 *$ & - & - & $0.113^{* * *}$ \\
\hline Intent_sc & - & - & $-0.064^{*}$ & - & - & - \\
\hline ICT_science & $0.134 * * *$ & $0.088 * * *$ & $0.052 * *$ & $0.067 * *$ & $0.175 * * *$ & $0.080 *$ \\
\hline Female & $-0.130 *$ & $-0.501 * * *$ & - & - & $-0.081 *$ & $-0.079 *$ \\
\hline Human & $0.196 * *$ & $0.176^{* * *}$ & - & $0.160 * * *$ & $-0.082 *$ & - \\
\hline ICT_secon & - & - & - & - & - & - \\
\hline HEPar & - & - & - & - & - & - \\
\hline $\begin{array}{l}\text { Adj. } R^{2} \\
\text { F }\end{array}$ & 0.053 & 0.099 & 0.030 & 0.031 & $\begin{array}{l}0.059 \\
7.23 * * *\end{array}$ & $\begin{array}{l}0.026 \\
3.69 * * *\end{array}$ \\
\hline \multicolumn{7}{|l|}{$\begin{array}{l}* \mathrm{p}<0.05 \\
* * \mathrm{p}<0.01 \\
* * * \mathrm{p}<0.001\end{array}$} \\
\hline
\end{tabular}


In the identity commitment model, the best predictor for the frequency of use of a PC is the conviction of students that a researcher needs sufficient ICT knowledge (see Table 12). The more they believe this, the more frequently PCs are used, both for study and non-study purposes. Frequent use of a PC for study is also supported - and this is not what was expected - by a stronger intention of the student to become something other than a researcher, and by a stronger orientation toward a profession. Frequent use of a PC for non-study purposes, in turn, is supported by the belief of a student that ICT is needed to carry out scientific research. In addition, the contextual factors are good predictors for PC use. Female students spend less time on a PC than men, and science students less time than humanities students.

Students who think that researchers need appropriate ICT knowledge will use all kinds of ICT instruments more often for both non-study and study purposes than those who do not hold this opinion as strongly (see Table 12). This is also true for students (as far as they need the instruments for study purposes) who are more vocationally orientated. Moreover, students with a positive attitude toward research will more frequently use these ICT instruments for study than other students will. However, unexpectedly, students who are more inclined toward becoming a researcher will use all these ICT instruments less often. With regard to non-study purposes, the more positive students are about their academic capabilities the more they use ICT instruments; humanities students will use ICT instruments more frequently than science students. It should be noted that gender and having attended an ICT course in secondary school are not adequate predictors here.

The use of ICT programs for both study and non-study purposes can be predicted by ICT_science and gender (see Table 12). Students who believe that researchers need a good knowledge of ICT will use ICT programs more than other students will. When programs are used for study or non-study purposes, the scores for male students are higher than for female students. Students who are aiming for an occupation other than a researcher also use ICT programs more frequently for non-study tasks than other students. It should be noted that ICT course experience in secondary school and the education level of the parents do not contribute to making better predictions for the frequency of using ICT programs.

\section{Discussion}

To begin with, an important limitation of our research must be pointed out. It should be noted that this attempt to link ICT learning experience and identity commitment to ICT use covers only second and third year bachelor's students at one university. To extrapolate the conclusions, a replication of the research in other universities and countries would be needed. Nevertheless, it is reasonable to assume that similar results would be found for universities and countries where ICT holds a similar position in the education system and in society. 
At a university, it is often taken for granted that all students are familiar with basic ICT skills. Indeed, most students will have grown up in families where a computer was present, and in primary and secondary education PCs are a normal part of school life. To a certain extent, our observations confirm this picture: most students know a lot about working with a word processor, they know how to prepare presentations using a program, how to maintain a computer, and are also familiar with using an Internet browser. This is, however, less true for working with spreadsheets and databases and new forms of communication. In order to see these differences among students we constructed a new observation instrument. First, 123 items covering the ICT skills a student was supposed to have, were presented to a sample of students. Based on this test, we then reduced the instrument to 49 items. We are aware that this approach relies on self-observation by the students, and that accordingly a discrepancy is possible between data obtained by the observation of actual skills by an independent observer and data collected based on self-perception. Nevertheless, by making the questions very specific we were able to obtain a diversified picture of ICT skills as perceived by the students. The frequency of ICT use was approached the same way: students described how often they used a PC for a particular purpose, how often they used different ICT instruments, and how often they applied specific ICT programs. Working with 53 items, students were asked to think more carefully about the frequency of use of many basic characteristics of ICT. Again, this might differ from an external observation (for instance automated tracking), but produces a reliable picture of what students think with regard to how often they use basic parts of ICT.

Research has shown that ICT learning experience at home has positive effects on mastering ICT skills in primary and secondary education (Anastasiades et al. 2008; Aslanidou and Menexes 2008; Barron et al. 2010; Vekiri 2010a; Zhao et al. 2010). However, among bachelor's students we did not find that PC use by parents and siblings at home (Home_pc) or at work (Work_pc), and the amount of ICT skills the students learned at home (Home_learn) were significant predictors for mastering ICT skills or for the frequency of ICT use. It is possible that a more in-depth analysis of what parents and siblings actually do together with their children on a PC and the Internet could confirm the importance of the first learning experience of these youngsters.

It was hypothesized that students who look to pursuing a career as a scientific researcher would master more ICT skills and use ICT more, because these can be perceived as a necessary part of carrying out research and because some structural characteristics of an information system resemble scientific research. This hypothesis is only partially confirmed by our data. This may be the result of bachelor's students having a somewhat vague idea of their future profession, or of their perception of the job of a scientific researcher. Therefore, it would be interesting to test this hypothesis among master's and $\mathrm{PhD}$ students. 
Students who attended university courses where a PC is used regularly in class did not show better results than other students for ICT skills or the frequency of ICT use. This is no surprise, since these courses are not intended to teach basic ICT skills. The position is totally different for ICT courses attended in secondary school (ICT_secon), which seems to be a good predictor for mastering ICT skills.

An unexpected relationship is also found between the education level of the parents and mastering ICT skills. In the learning experience model, four relationships are found where students from families whose parents graduated in higher education were less capable than other students of applying some ICT skills, whereas research has shown that in primary or secondary schools, students of higher educated parents do better or are better supported by their parents (Aslanidou \& Menexes 2008; Barron et al. 2010; Zhao et al. 2010). More in-depth research should provide an explanation.

\section{Conclusion}

In this article, we present two hypotheses regarding the ICT skills and the frequency of ICT use by university students. In line with Dewey's learning theory, the first hypothesis is that a positive ICT learning experience at home, in school, and with peers will contribute to a higher level of mastering ICT skills and a more frequent use of ICT among bachelor's students (the learning experience hypothesis). The second hypothesis is based on the use of ICT in research and the similarity between the structure of information systems and scientific research. From this, we hypothesize that students who strive for an identity commitment that is directed toward scientific research will be more inclined to learn ICT skills and show a higher frequency of ICT use. Both hypotheses are tested with the inclusion of some important contextual variables: gender, domain of study, ICT course in secondary school or at the university, and the education level of parents.

The explanation of different levels of ICT skills provided by the learning experience model is confirmed, but not very strongly overall, and not equally for all types of ICT skills. The model can explain the largest proportion of the variance in maintenance of a computer and the technical use of a browser. In descending proportion of explained variance, these two skills are followed by the three of working with a spreadsheet, communication skills, information collection with a browser, working with databases, two forms of working with a presentation program, and working with a word processor.

The best predictors for most of the skills is the age of the students when they first started using a PC (the lower the age, the higher the scores), self-study, gender (men score higher than women), and having attended an ICT course in secondary school. Instruction from teachers is important for working with spreadsheets and databases. It is also noteworthy here, that the use of a PC at home and at work by parents 
and siblings, what the student learned of ICT at home, and the support of peers and teachers does not play a significant role, although research has shown that these factors are important in primary and secondary schools (Vekiri 2010a; Aslanidou and Menexes 2008; Barron et al. 2010; Zhao et al. 2010 ).

The learning experience model also explains some of the variance in the frequency of ICT use. It explains $17.5 \%$ of the variance in the frequency of PC use for non-study oriented tasks, but for all other frequencyrelated dependent variables the proportion of explained variance is much smaller.

Predictions of the frequency of ICT use can be improved taking into account the age when students started to use a PC (the lower the age, the higher the use), self-study (only for non-study purposes), domain of study (humanities students mostly score higher than science students), and gender (women score lower than men). Peer support is a significant predictor for the frequency of computer use and of ICT programs, and this applies to both study and non-study purposes. What had been learned at home is not recognized as a factor that could predict the frequency of ICT use by the students. This is the same for ICT courses attended in secondary school and at the university, or the education level of the parents.

The identity commitment model can also explain parts of the variance in the ICT skills of students. The explained proportion of the variance, however, is very different for each of the ICT skills. This model can explain two fifths of the variance in the technical use of a browser, but for all other ICT skills the results are lower, sometimes substantially so. The most important predictors of this model are the belief of students that researchers need an appropriate knowledge of ICT, a positive attitude toward scientific research, gender (lower scores for women than for men), and having attended an ICT course in secondary school. The other explanatory variables have very diversified impacts. Each of them helps to improve a prediction, but for very different ICT skills. The reasons these differences occur are unclear and require more research. It should also be mentioned that the intention to become a researcher is not a strong predictor: only the skill to perform style changes in spreadsheets seems to be better developed among research-oriented students.

The identity commitment model is less successful in explaining the frequency of ICT use. Only one explanatory factor plays a significant role in the explanation of the six dependent variables, i.e. the belief of the students that researchers need ICT. The more students think that a researcher needs a good knowledge of ICT, the more frequently they use a PC, ICT instruments, and ICT programs - and this applies to both study and non-study purposes. The other factors do not have the same predictive value and their value differs for each of the dependent variables. In other words, our hypothesis that students who want to become a researcher will score higher for using ICT is not supported by the data. On the contrary, 
students who want to become a researcher do not show more frequent use of a computer or ICT programs, and they actually use ICT instruments for study less frequently than other students do.

In short, the learning experience hypothesis and the identity commitment hypothesis are both only partially confirmed by our research. We can, however, conclude in general that a relationship does exist between the ICT learning experience, the research-oriented identity commitment of bachelor's students, and their command of ICT skills on the one hand and the frequency of use of a computer, ICT instruments, and ICT programs on the other. However, at the same time we must acknowledge that this is a very diversified relationship, which is not always equally strong for all aspects of ICT skills and ICT use. In order to better understand these differences, future research will have to dig deeper into the particularities of divergent ICT skills and ICT uses.

\section{Implications}

This study shows that bachelor's students attain a rather high proficiency in some ICT skills, At the same time, however, it documents that this is not the case for all ICT skills. In particular many students are not very familiar with, and experience problems when working with databases, spreadsheets, and modern communication systems. Our data shows that ICT training in secondary school improves having command of ICT skills. It would therefore be wise to invest more in ICT training in secondary school. For those students who still need more support, universities should provide this. And this would be fruitful for all students, as students who are trained to become researchers or other professionals will experience difficulties in their professional life without an adequate knowledge of basic ICT skills.

It is perhaps not a surprise that students in our research score higher on word processing than on working with digital spreadsheets or databases. For study, word processing is used more frequently than any other ICT program. This makes students more familiar with this program: about $48 \%$ of the students applied word processing more than twice or three times a week. Only the local virtual learning environment was applied more frequently by more students (95\%). The figures for the use of digital spreadsheets (9\%) and databases (5\%) are much lower. More frequent application of these programs, where meaningful, may make students more familiar with these programs.

Table 7 has shown that self-study is an important variable for the explanation of the level of mastering ICT skills. This self-study implies the use of the PC and the Internet to become more acquainted with ICT. In a similar vein, learning of other subjects may also take advantage of the help of the PC and the Internet. This learning may take the form of blended learning, where classroom teaching is supported by computermediated activities, and offers the student the means to improve knowledge by self-study. 
A lot of research (for instance: Alshumaimeri 2011; Morley 2012; Bidaki et al. 2013; Martin and Ertzberger 2013) has shown that blended learning has advantages over other forms of learning. At the university in our research, blended learning appears to be not widely spread. During last semester only $53 \%$ of the students used a PC during classes, and for only 50\% of these students this happened weekly and for only $20 \%$ several times a week. The frequent use of the local virtual learning environment could give the impression that blended learning is part of the culture in this university. Former research (Bruneel et al. 2011) denies this. Most students use the virtual learning platform as "a place to gather information". The low frequencies of use of ICT programs for study (Table 4) also let us surmise that blended learning is not yet widely spread in this university. This means that there is still a lot of work to do in order to use all the advantages of blended learning.

Although universities are supposed to prepare students for conducting research, the bachelor's students in our study scored no more than 2.56 on a scale of 1 to 5 measuring their intention to become a researcher. They do not seem very enthusiastic about becoming researchers. If universities, though, want to fulfill their mission in the future they need motivated researchers. It will be a challenge for them to find ways to motivate their students to become researchers. Explaining them how ICT can support research might be one way to achieve that. 


\section{References}

Akyol, G., Sungur, S., \& Tekkaya, C. (2010). The contribution of cognitive and metacognitive strategy use to students' science achievement. Educational Research and Evaluation, doi:

$10.1080 / 1380361100367234816$

Alshumaimeri, Y. (2011). The effects of wikis on foreign language students writing performance.

Procedia - Social and Behavioral Sciences, doi:10.1016/j.sbspro.2011.11.139

Anastasiades, P. S., Vitalaki, E., \& Gertzakis, N. (2008). Collaborative learning activities at a distance via interactive videoconferencing in elementary schools: Parents' attitudes. Computers \& Education, doi:10.1016/j.compedu.2007.02.003

Aslanidou, S. \& Menexes, G. (2008). Youth and the Internet: Uses and practices in the home. Computers \& Education, doi:10.1016/j.compedu.2007.12.003

Barron, B., Walter, S. E., Martin, C. K., \& Schatz, C. (2010). Predictors of creative computing participation and profiles of experience in two Silicon Valley middle schools. Computers \& Education, doi:10.1016/j.compedu.2009.07.017

Becker, J. D. (2006). Digital equity in education: A multilevel examination of diffrences in and relationships between computer access, computer use, and state-level technology policies. Education Policies Archives Analysis, 15 (3), http://epaa.asu.edu/epaa/v15n3/. Accessed 15 July 2013.

Bennett, J. , \& Hogarth, S. (2009). Would you want to talk to a scientist at a party? High school students' attitudes to school science and to science. International Journal of Science Education, doi: $10.1080 / 09500690802425581$

Bennett, R. (2009). Academic self-concept among business students in a recruiting university: definition, measurement and potential effects. Journal of Further and Higher Education, doi:

$10.1080 / 03098770902856678$

Bidaki, M. Z., Sanati, A. R., \& Ghannad, F. R. (2013). Producing and introducing mobile books, as a new model of providing learning content in medical sciences. Procedia - Social and Behavioral Sciences, doi: 10.1016/j.sbspro.2013.06.019

Broos, A. (2005). Gender and information and communication technologies (ICT) anxiety: male selfassurance and female hesitation. CyberPsycholgy \& Behavior, 8 (1), 21-31. 
Bruneel, S., Elen, J., De Wit, K., \& Verhoeven, J. C. (2011). Study and non-study related technologies use of Flemish students in higher education. In K. Moyle, \& G. Wijngaard, Student reactions to learning with technologies: Perceptions and outcomes. (pp. 227-248). Hershey (PA) IGI Global.

Burke, P. J., \& Reitzes, D. C. (1991). An identity theory approach to commitment. Social Psychology Quarterly, 54 (3), 239-251.

Carlsson, C., Carlsson, J., Hyvönen, K., Puhaikanen, P., \& Walden, P. (2006). Adoption of Mobile Devices/Services - Searching for Answers with the UTAUT. Proceedings of the 39th Hawai International Conference on sytem sciences.

http://www2.computer.org/plugins/dl/pdf/proceedings/hicss/2006/2507/06/250760132a.pdf?template=1\&l oginState=1\&userData=anonymous-IP\%253A\%253A127.0.0.1). Accessed 15 July 2013.

Chatzoglou, P. D., Sarigiannidis, L., Vraimaki, E., \& Diamantidis, A. (2009). Investigating Greek employees' intention to use web-based training. Computers \& Education, doi:10.1016/j.compedu.2009.05.007

Chen, S. Y., \& Fu, Y. C. (2009). Internet use and academic achievement: gender differences in early adolescence. Adolescence, 44 (176), 797-842.

Cheung, D. (2009). Developing a scale to measure students' attitudes toward chemistry lessons.

International Journal of Science Education, doi: 10.1080/09500690802189799

Cho, V., Cheng, T. C., \& Lai, W. M. (2009). The role of perceived user-interface design in continued usage intention of self-paced e-learning tools. Computers \& Education,

doi:10.1016/j.compedu.2009.01.014

Colley, A., \& Comber, C. (2003). Age and gender differences in computer use and attitudes among secondary school students: what has changed? Educational Research, doi:

10.1080/0013188032000103235

Cox, M. (2013). Formal to informal learning with IT: resaerch challenges and issues for e-learning. Journal of Computer Assisted Learning, doi: 10.1111/j.1365-2729.2012.00483.x (in press).

De Wit, K., Heerwegh, D., \& Verhoeven, J.C. (2012). Changes in the basic ICT skills of freshmen between 2005 and 2009: Who's catching up and who's still behind? Education and Information Technologies, doi: 10.1007/s10639-011-9154-z 
Demir, I., Kiliç, S., \& Ünal, H. (2010). Effects of students' and schools' characteristics on mathematics achievement: findings from PISA 2006. Procedia Social and Behavioral Sciences, doi:

10.1016/j.sbspro.2010.03.472

Dewey, J. (1938). Education and experience. http://www.schoolofeducators.com/wpcontent/uploads/2011/12/EXPERIENCE-EDUCATION-JOHN-DEWEY.pdf. Accessed 14 March 2013.

Dewey, J. (1933 (1960)). How we think. Lexington, Massachusetts: D.C. Heath and Company.

Dewey, J. (1917). The Need for A Recovery of Philosophy. In J. Dewey (Ed.), Creative Intelligence: Essays in the Pragmatic Attitude (pp. 3-69). New York: Holt.

DiStefano, C., Zhu, M., \& Mîndrilă, D. (2009). Understanding and using factor scores: Considerations for the applied researcher. Practical Assessment, Research \& Evaluation , 14 (20), 1-11. http://pareonline.net/pdf/v14n20.pdf . Accessed 27 September 2013.

ECDL. (2010). ECDL syllabus 5.0. Utrecht: ECDL Nederland NV.

Eow, Y. L., bte Wan Ali, W. Z., bt. Mahmud, R., \& Baki, R. (2009). Form one students' engagement with computer games and its effect on their academic achievement in a Malaysian secondary school.

Computers \& Education, doi:10.1016/j.compedu.2009.05.013

Evans, K. G. (2000). Reclaiming John Dewey: democary, inquiry, pragmatism, and public management. Administration \& Sociey, doi: 10.1177/00953990022019452

George, R. (2006). A cross-domain analysis of change in students' attitudes toward science and attitudes about the utility of science. International Journal of Science Education, doi:

$10.1080 / 09500690500338755$

Germann, P. J. (1988). Development of the attitude toward science in school assessment and its use to investigate the relationship between science achievement and attitude toward science in school. Journal of Research in Science Teaching, 25 (8), 689-703.

Hargittai, E. (2010). Digital na(t)ives. Variation in Internet skills and uses among members of the "Net Generation', Sociological Inquiry, doi: 10.1111/j.1475-682X.2009.00317.x

Jeffrey, L., Hegarty, B., Kelly, O., Penman, M., Coburn, D., \& McDonald, J. (2011). Developing digital information literacy in higher education: obstacles and supports. Journal of Information Technology Education, 10, 383-413. 
Kaminski, K., Switzer, J., \& Gloeckner, G. (2009). Workforce readiness: a study of university students' fluency with information technology. Computers \& Education, doi:10.1016/j.compedu.2009.01.017

Kind, J., Jones, P., \& Barmby, P. (2007). Developing Attitudes towards Science Measures. International Journal of Science Education, doi: 10.1080/09500690600909091

Kolb, A. Y., \& Kolb, D. A. (2005). Learning styles and learning spaces: enhancing experiential learning in higher education. Academy of Management Learning \& Education, 4 (2), 193-212.

Kubiatko, M., \& Vlckova, K. (2010). The relationship between ICT use and science knowledge for Czech students: a secondary analysis of PISA. International Journal of Science and Mathematics Education, 8 (3), 523-543.

Lee, B. C., Yoon, J. O., \& Lee, I. (2009). Learners' acceptance of e-learning in South Korea: Theories and results. Computers \& Education, doi:10.1016/j.compedu.2009.06.014

Lee, M. C. (2010). Explaining and predicting users' continuance intention toward e-learning: An extension of the expectation-confirmation model. Computers \& Education,

doi:10.1016/j.compedu.2009.09.002

Lee, Y. C. (2008). The role of perceived resources in online learning adoption. Computers \& Education, doi:10.1016/j.compedu.2007.01.001

Luu, K., \& Freeman, J. G. (2011). An analysis of the relationship between information and communication technology (ICT) and scientific literacy in Canada and Australia. Computers \& Education, doi:10.1016/j.compedu.2010.11.008

Martin, F., \& Ertzberger, J. (2013). Here and now mobile learning: an experimental study on the use of mobile technology. Computers \& Education, doi: 10.1016/j.compedu.2013.04.021

McCleary, L., \& Brown, G. T. (2003). Association between nurses' education about research and their research use. Nurse Education Today, doi:10.1016/S0260-6917(03)00084-4

McCloskey, D. J. (2008). Nurses' perceptions of research utilization in a corporate health care system. Journal of Nursing Scholarship, 40 (1), 39-45.

McMahon, G. (2009). Critical thinking and ICT integration in a Western Australian secondary school. Educational Technology \& Society, 12 (4), 269-281. 
Morley, D. A. (2012). Enhancing networking and proactive learning skills in the first year university experience through the use of wikis. Nurse Education Today, doi:10.1016/j.nedt.2011.03.007

O’Brian, J. A., \& Marakas, G. M. (2009) Management Information Systems (Ninth Edition). Boston, Burr Ridge (IL), Dubuque (IA), New York, San Francisco: McGraw Hill Irwin.

Papanastasiou, E. C., Zembylas, M., \& Vrasidas, C. (2005). An examination of the Pisa Database to explore the relationship between computer use and science achievement. Educational Research and Evaluation, doi: 10.1080/13803610500254824

Peter, J., \& Valkenburg, P. (2006). Adolescents' Internet use: Testing the "disappearing digital divide" versus the "emerging digital differentiation" approach. Poetics, doi:10.1016/j.poetic.2006.05.005

Pole, C., \& Lampard, R. (2002). Practical Social Investigation. Qualitative and Quantitative Methods in Social Research. Harlow: Prentice Hall.

Salajan, F. D., Schönwetter, D. J., \& Cleghorn, B. M. (2010). Student and faculty inter-generational digital divide: fact or fiction. Computers \& Education, doi: 10.1016/j.compedu2010.06.017

Strømsø, H. I., Grottum, P., \& Lycke, K. H. (2004). Changes in student approaches to learning with the introduction of computer-supported problem-based learning. Medical Education, doi:10.1046/j.13652923.2004.01786.x

Teo, T., Lee, C. B., Chai, C. S., \& Wong, S. L. (2009). Assessing the intention to use technology among pre-service teachers in Singapore and Malaysia: A multigroup invariance analysis of the Technology Acceptance Model (TAM). Computers \& Education, doi:10.1016/j.compedu.2009.05.017

Tuan, H., Chin, C. C., \& Shieh, S. H. (2005). The development of a questionnaire to measure students' motivation towards science learning. International Journal of Science Education, doi: $10.1080 / 0950069042000323737$

van Dijk, J. A. (2006). Digital divide research, achievements and shortcomings. Poetics, doi:10.1016/j.poetic.2006.05.004

Vekiri, I. (2010a). Socioeconomic differences in elementary students' ICT beliefs and out-of-school experiences. Computers \& Education, doi:10.1016/j.compedu.2009.09.029

Vekiri, I. (2010b). Boys' and girls' ICT beliefs: Do teachers matter? Computers \& Education, doi:10.1016/j.compedu.2009.11.013 
Vekiri, I. \& Chronaki, A. (2008). Gender issues in technology use: Perceived social support, computer self-efficacy and value beliefs, and computer use beyond school. Computers \& Education, doi:10.1016/j.compedu.2008.01.003

Verhoeven, J.C., Heerwegh, D., \& De Wit, K. (2010). Information and communication technologies in the life of university freshmen: An Analysis of change. Computers \& Education, doi:

10.1016/j.compedu.2009.12.002

Vermunt, J. (1994). Scoring key for the inventory of learning styles (ILS) in higher education. Tilburg: Tilburg University.

Volman, M, \& van Eck, E. (2001). Gender equity and information technology in education: the second decade. Review of Educational Research, 71 (4), 613-634.

Wang, Y., Wu, M., \& Wang, H. (2009). Investigating the determinants and age and gender differences in the acceptance of mobile learning. British Journal of Educational Technology, doi:10.1111/j.14678535.2007.00809.x

Wareing, C. (1982). Developing the WASP:Wareing attitudes toward science protocol. Journal of Research in Science Teaching, 19 (8), 639-645.

Wareing, C. (1990). A survey of antecedents of attitudes toward science. Journal of Research in Science Teaching, 27 (4), 371-386.

Won, S. J., \& Han, S. (2010). Out-of-School activities and achievement among middle school students in the USA and South Korea. Journal of Advanced Academics, 21 (4), 628-661.

Wu, Y., Tao, Y., \& Yang, P. (2007). Using UTAUT to explore the behavior of 3G mobile communication users. Proceedings of the 2007 IEEE IEEM, (pp. 199-203).

http://ieeexplore.ieee.org/ielx5/4419130/4419131/04419179.pdf?arnumber=4419179. Accessed 4 July 2012.

Zhao, L., Lu, Y., Huang, W., \& Wang, Q. (2010). Internet inequality: The relationship between high school students' Internet. Computers \& Education, doi:10.1016/j.compedu.2010.05.010

Zwass, V. (2012). Information system. Encyclopedia Britannica Online.

http://www.britannica.com/EBchecked/topic/287895/information-system. Accessed 15 July 2013. 